\title{
PHYTOSOCIOLOGICAL STUDIES ON CALCAREOUS SCREES FROM MERIDIONAL CARPATHIANS (ROMANIA)
}

\author{
Monica Angela Neblea ${ }^{1, *}$, Mădălina Cristina Marian' ${ }^{1}$ \\ ${ }^{1}$ University of Pitesti, Targu din Vale Street, no. 1, Pitesti, Romania
}

Current Trends in

Natural Sciences

\begin{abstract}
The calcareous screes are very well represented in Meridional Carpathians, especially in Piatra Craiului Mountains. The paper analyzes the vegetation of these natural habitats from phytosociological point of view. There are 11 plant associations characteristic for calcareous screes in this region, as follows: Cerastio lerchenfeldiani-Papaveretum Boşcaiu, Täuber et Coldea 1977, Cardaminopsio neglectae-Papaveretum Coldea et Pânzaru 1986, Acino-Galietum anisophylli Beldie 1967, Doronico columnae-Rumicetum scutati Boşcaiu et al. 1977, Saxifragetum moschatae-aizoidis Boşcaiu 1971, Cerastio transsilvanici-Galietum lucidi M. Boșcaiu et al. 1998, Achnatheretum calamagrostis Br.-Bl. 1918, Gymnocarpietum robertianae (Kaiser 1926) Tx. 1937, Sedo fabariae-Geranietum macrorrhizi Boşcaiu et Täuber 1977, Thymetum comosi Pop et Hodişan 1963, Parietarietum officinalis Csürös 1958. The plant associations were characterized and the Relative Euclidean distance was calculated on the basis of the Ward method.

The hierarchical analysis revealed the distribution of the plant associations in two clusters corresponding to the Papavero-Thymion pulcherrimi I. Pop 1968 and Stipion calamagrostis Jenny-Lips ex Br.-Bl. 1950 alliances.
\end{abstract}

Keywords: calcareous screes, Meridional Carpathians, plant associations, Romania

\section{INTRODUCTION}

„The most representative screes of the Southern Carpathians are found in Piatra Craiului Mountains, especially on the western slope, in the central area known as the Grand Grohotiş." (Doniţă et al., 1992)

The screes from Piatra Craiului Mountains are in different phases of fixation, starting with the mobile ones, with a poorly developed or even absent grassy layer up to screes covered by plant associations of forest, hay, meadows, depending on the local climatic conditions and the solification stage (Beldie, 1952).

As the process of pedogenesis and stabilization of the substrate evolves, the screes from Piatra Craiului Mountains going through a series of successive phases with syntaxonomically well-defined plant associations or more difficult to affiliate them (Cerastio transsilvanici-Galietum lucidi, Gymnocarpietum robertianae, Saxifrago-Poëtum nemoralis, Carici polyphyllae-Arrhenatheretum bulbosae) in typical communities for the stabilization (Seslerio haynaldianae-Caricetum sempervirentis, Rhododendro-Pinetum mugo, Violo declinatae-Nardetum) and climax stage (Hieracio rotundati-Piceetum) (Pop, 2009). 


\begin{tabular}{lcr}
\hline & $\begin{array}{c}\text { Current Trends in Natural Sciences } \\
\text { Vol. 10, Issue 19, pp. 209-219, 2021 } \\
\text { https://doi.org/10.47068/ctns.2021.v10i19.028 }\end{array}$ & Current Trends in Natural Sciences (CD-Rom) \\
\cline { 2 - 2 } Current Trends in Natural Sciences (on-line) & ISSN: 2284-9521 \\
ISSN: 2284-953X & ISSN-L: 2284-9521 \\
ISSN-L: 2284-9521 & \\
\hline
\end{tabular}

The majority of plant communities of the calcareous screes from Bucegi Mountains are those characteristic of the habitat 8120 Calcareous and calcashist screes of the montane to alpine levels (Thlaspietea rotundifolii). The coenoses on the limestone screes are arranged mosaically. In a first stage, the substrate is colonized by phytocoenoses of the Cerastio lerchenfeldiani-Papaveretum, Cardaminopsio neglectae-Papaveretum, Acino-Galietum anisophylli. Subsequently, as the organic matter accumulates and the soil is formed, cormophytes stabilize the scree, such as: Vaccinium myrtillus, V. vitis-idaea, Juniperus communis subsp. alpina, Rhododendron myrtifolium, Pinus mugo (http://www.bucegipark.ro/).

There are two types of plant communities for Leaota Mountains, either on unfixed, sunny and wet screes (Gymnocarpietum robertianae) or on semi-fixed screes (Thymetum comosi) (figure 1,2).

Csürös (1953) indicates the directions of the screes evolution in the Făgăraş Mountains. Coenoses with Papaver alpinum subsp. corona-sancti-stephani can evolve either to shrubs with Salix reticulata, Dryas octopetala (in mesophilic conditions), or to those with Salix retusa in hygrophilous conditions. Shrubs with Salix spp. offer favorable conditions for groups of Rhododendron myrtifolium. The stabilization of screes is achieved by the phytocoenoses of the Luzuletum obscurae (Szafer et al. 1927) Dúbracová 2000.

There are characteristic plant associations for mobile or semi-fixed calcareous screes (Doronico columnae-Rumicetum scutati, Thymetum comosi, Gymnocarpietum robertianae, Parietarietum officinalis) in the central group of the Southern Carpathians (Căpăţânii Mountains, BuilaVânturariţa Mountains, Cindrel Mountains, Parâng Mountains).

In the Retezat Mountains, large areas with calcareous screes are located above the area occupied by mountain pine. Piatra Iorgovanului Mount offers favorable ecological conditions for the communities like Cerastio lerchenfeldiani-Papaveretum, Acino-Galietum anisophylli, Doronico columnae-Rumicetum scutati and Saxifragetum moschatae-aizoidis, installed on both mobile and semi-fixed, sunny or wet screes.

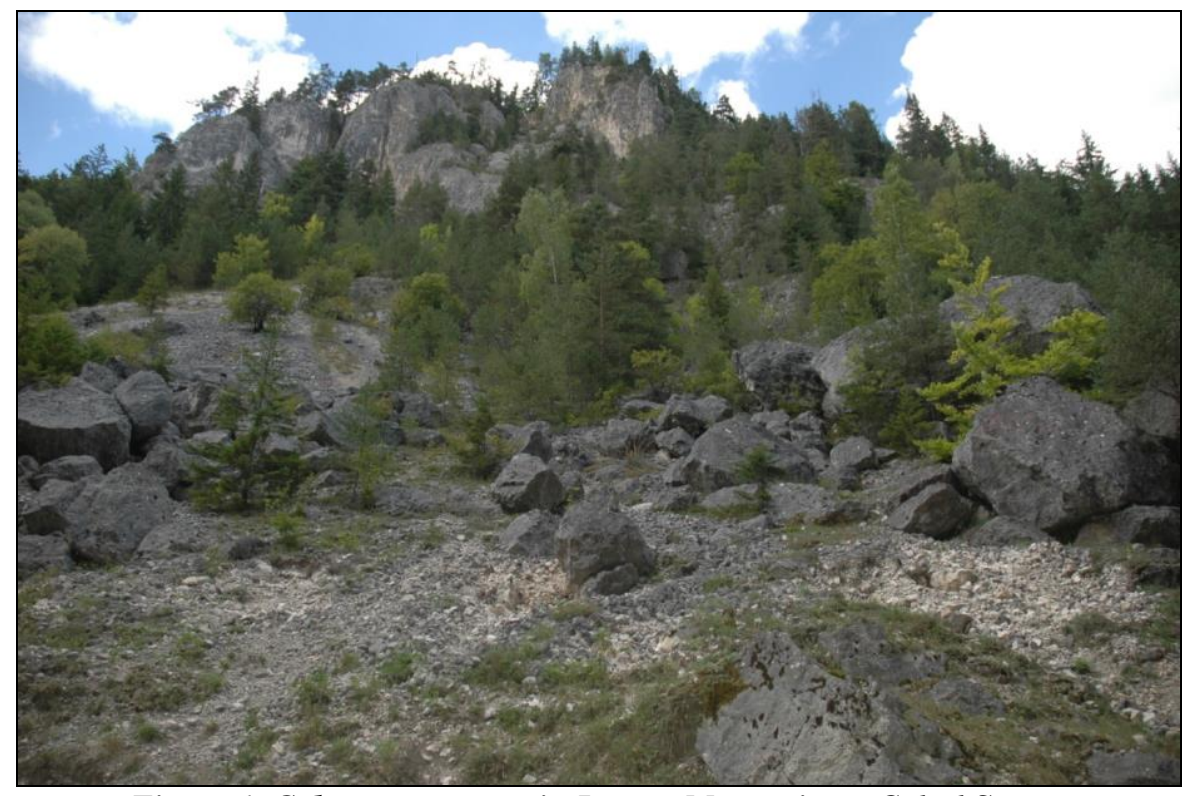

Figure 1. Calcareous screes in Leaota Mountains - Colțul Surpat 


\begin{tabular}{|c|c|}
\hline & $\begin{array}{l}\text { Current Trends in Natural Sciences } \\
\text { Vol. 10, Issue 19, pp. 209-219, } 2021 \\
\text { https://doi.org/10.47068/ctns.2021.v10i19.028 }\end{array}$ \\
\hline $\begin{array}{l}\text { Current Trends in Natural Sciences (on-line) } \\
\text { ISSN: 2284-953X } \\
\text { ISSN-L: 2284-9521 }\end{array}$ & $\begin{array}{r}\text { Current Trends in Natural Sciences (CD-Rom) } \\
\text { ISSN: 2284-9521 } \\
\text { ISSN-L: 2284-9521 }\end{array}$ \\
\hline
\end{tabular}

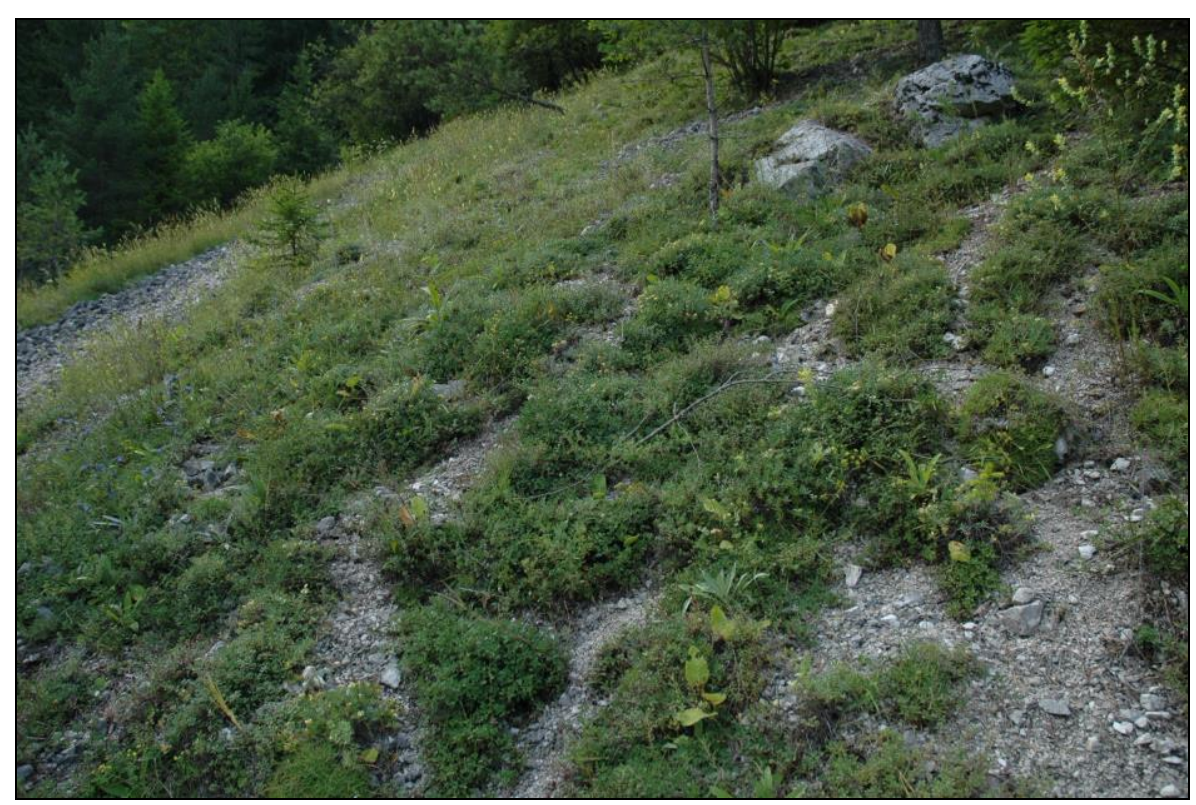

Figure 2. Thymetum comosi Pop et Hodişan 1963 teucrietosum montani (Csürös 1985) Coldea 1991 in Leaota Mountains - Colţii Ghimbavului

Csürös et al. (1956a) highlights the directions of evolution of the screes in the Retezat Mountains. Thus, on the mobile screes, the communities with Papaver alpinum subsp. corona-sancti-stephani can evolve either to sesleriets or to associations with Dryas octopetala. With the lying fallow of the substrate, the groups with Sesleria spp. can continue the ecological succession to tall-herbs and meadows with Festuca rubra. Finally, under anaerobic conditions, the stations are populated by mountain pine.

The coenoses of the Thlaspietalia rotundifolii at the base of the Cretaceous and Jurassic limestone rocks are characteristic for Godeanu Mountains (Boşcaiu, 1971).

Muică (1995) identifies five plant associations from Thlaspietea rotundifolii developed both on mobile and fixed screes in the Vâlcan Mountains. Rumex scutatus is an important species of mobile screes in the Sohodol Gorges, while in sunny or even shady stations Geranium macrorrhizum is distinguished. On the thicked screes appear phytocoenoses with Parietaria officinalis at the base of the slopes and communities of the Acino-Galietum anisophylli in the subalpine level.

Maloş (1977) cites four plant associations of the limestone screes from the upper basin of the Motru River, respectively: Gymnocarpietum robertianae, Sedo fabariae-Geranietum macrorrhizi, Thymetum comosi and Parietarietum officinalis.

Regarding the syntaxonomic diversity, the most numerous plant associations of the calcareous screes were identified in the Piatra Craiului Mountains and the Bucegi Mountains (6) while in the Vâlcan Mountains are 5 and 4 for Retezat, Țarcu Godeanu, Cernei, Făgăraș (table 1).

In terms of frequency, the most common plant associations on calcareous screes in the Meridional Carpathians are: Gymnocarpietum robertianae (7 mountain massifs), Acino-Galietum anisophylli (7 mountain massifs), Doronico columnae-Rumicetum scutati (6 mountain massifs), Thymetum comosi (6 mountain massifs), Sedo fabariae-Geranietum macrorrhizi (6 mountain massifs), Saxifragetum moschatae-aizoidis (5 mountain massifs) (table 1). 


\section{Current Trends in Natural Sciences}

Vol. 10, Issue 19, pp. 209-219, 2021

https://doi.org/10.47068/ctns.2021.v10i19.028

Current Trends in Natural Sciences (on-line)

ISSN: 2284-953X

Current Trends in Natural Sciences (CD-Rom)

ISSN: 2284-9521

ISSN-L: 2284-9521

\section{Table 1. Distribution of plant associations of the calcareous screes}

\begin{tabular}{|c|c|}
\hline Mountainous Massif & Plant associations \\
\hline Retezat & $\begin{array}{l}\text { Cerastio lerchenfeldiani-Papaveretum Boşcaiu, Täuber et Coldea 1977; Acino-Galietum } \\
\text { anisophylli Beldie 1967; Doronico columnae-Rumicetum scutati Boşcaiu et al. 1977; } \\
\text { Saxifragetum moschatae-aizoidis Boşcaiu 1971 }\end{array}$ \\
\hline Ţarcu & $\begin{array}{l}\text { Acino-Galietum anisophylli Beldie 1967; Doronico columnae-Rumicetum scutati Boşcaiu et al. } \\
\text { 1977; Saxifragetum moschatae-aizoidis Boşcaiu 1971; Sedo fabariae-Geranietum macrorrhizi } \\
\text { Boşcaiu et Täuber } 1977\end{array}$ \\
\hline Godeanu & $\begin{array}{l}\text { Acino-Galietum anisophylli Beldie 1967; Saxifragetum moschatae-aizoidis Boşcaiu 1971; } \\
\text { Gymnocarpietum robertianae (Kaiser 1926) Tx. 1937; Sedo fabariae-Geranietum macrorrhizi } \\
\text { Boşcaiu et Täuber }\end{array}$ \\
\hline Cernei & $\begin{array}{l}\text { Achnatheretum calamagrostis Br.- Bl. 1918; Gymnocarpietum robertianae (Kaiser 1926) Tx. } \\
\text { 1937; Sedo fabariae-Geranietum macrorrhizi Boşcaiu et Täuber 1977; Parietarietum officinalis } \\
\text { Csürös } 1958\end{array}$ \\
\hline Mehedinţi & $\begin{array}{l}\text { Achnatheretum calamagrostis Br.- Bl. 1918; Gymnocarpietum robertianae (Kaiser 1926) Tx. } \\
\text { 1937; Sedo fabariae-Geranietum macrorrhizi Boșcaiu et Täuber } 1977\end{array}$ \\
\hline Vâlcan & $\begin{array}{l}\text { Doronico columnae-Rumicetum scutati Boşcaiu et al. 1977; Thymetum comosi Pop et Hodişan } \\
\text { 1963; Parietarietum officinalis Csürös 1958; Sedo fabariae-Geranietum macrorrhizi Boşcaiu et } \\
\text { Täuber 1977; Acino-Galietum anisophylli Beldie } 1967\end{array}$ \\
\hline Buila-Vânturariţa & $\begin{array}{l}\text { Doronico columnae-Rumicetum scutati Boşcaiu et al. 1977; Thymetum comosi Pop et Hodişan } \\
\text { 1963; Parietarietum officinalis Csürös } 1958\end{array}$ \\
\hline Căpăţânii & $\begin{array}{l}\text { Gymnocarpietum robertianae (Kaiser 1926) Tx. 1937; Thymetum comosi Pop et Hodişan 1963; } \\
\text { Parietarietum officinalis Csürös } 1958\end{array}$ \\
\hline Cindrel & Doronico columnae-Rumicetum scutati Boşcaiu et al. 1977 \\
\hline Leaota & Gymnocarpietum robertianae (Kaiser 1926) Tx. 1937; Thymetum comosi Pop et Hodişan 1963 \\
\hline Bucegi & $\begin{array}{l}\text { Cerastio lerchenfeldiani-Papaveretum Boşcaiu, Täuber et Coldea 1977; Cardaminopsio } \\
\text { neglectae-Papaveretum Coldea et Pânzaru 1986; Acino-Galietum anisophylli Beldie 1967; } \\
\text { Saxifragetum moschatae-aizoidis Boşcaiu 1971; Gymnocarpietum robertianae (Kaiser 1926) } \\
\text { Tx. 1937; Thymetum comosi Pop et Hodişan 1963 }\end{array}$ \\
\hline Făgăraş & $\begin{array}{l}\text { Cerastio lerchenfeldiani-Papaveretum Boşcaiu, Täuber et Coldea 1977; Acino-Galietum } \\
\text { anisophylli Beldie 1967; Doronico columnae-Rumicetum scutati Boşcaiu et al. 1977; } \\
\text { Saxifragetum moschatae-aizoidis Boşcaiu 1971 }\end{array}$ \\
\hline Piatra Craiului & $\begin{array}{l}\text { Cerastio lerchenfeldiani-Papaveretum Boşcaiu, Täuber et Coldea 1977; Acino-Galietum } \\
\text { anisophylli Beldie 1967; Cerastio transsilvanici-Galietum lucidi M. Boşcaiu et al. 1998; } \\
\text { Gymnocarpietum robertianae (Kaiser 1926) Tx. 1937; Thymetum comosi Pop et Hodişan 1963; } \\
\text { Sedo fabariae-Geranietum macrorrhizi Boşcaiu et Täuber } 1977\end{array}$ \\
\hline
\end{tabular}

\section{MATERIALS AND METHODS}

The Meridional Carpathians are located between Cerna-Timiș-Bistra-Hațeg-Ștei-Orăștie Pass and Prahova Valley and are known as Transylvanian Alps.

The study was based, mainly, on information from scientific literature (articles, books, monographs, doctoral thesis) related to calcareous screes (Alexiu, 1998; Bartók et Irimia, 2016; Beldie, 1952; Beldie, 1967; Boșcaiu, 1971; Boșcaiu et al., 1977; Csűrös et al., 1956a; Csűrös et al., 1956b; Diaconescu, 1973; Drăghici, 1994; Drăgulescu, 1995; Maloș, 1977; Mihăilescu, 2001; Neblea, 2007, 2012, 2016; Nicolae-Biță, 2005; Păun and Popescu, 1978; Pop, 2009; Popescu, 1974; Pușcaru-Soroceanu et al., 1981; Răduțoiu, 2008; Sanda and Popescu, 1976; Sanda et al., 1977; Sanda and Popescu, 1991; Sanda et al., 1996; Schneider-Binder, 1970; Stancu, 2005; Voik, 1976; Voik and Schneider-Binder, 1978). 
Syntaxonomical classification elaborated by Coldea et al. (2017) was used.

In order to establish the degree of floristic similarity between the plant associations on the calcareous screes, a dendrogram was developed using the SYSTAT program version 10.2. The Relative Euclidean distance calculated on the basis of the Ward method was chosen as a similarity index (Neblea and Marian, 2020).

321 phytosociological surveys belonging to 11 plant associations recorded from Meridional Carpathians were analysed. Due to the large number of surveys analyzed for calcareous screes, SYSTAT version 10.2 did not allow a clear differentiation of clusters. In this case, the surveys were grouped by stations, resulting 104 units that were compared.

\section{RESULTS AND DISCUSSIONS}

The hierarchical analysis revealed the distribution of the plant associations in two clusters corresponding to two alliances Papavero-Thymion pulcherrimi I. Pop 1968 and Stipion calamagrostis Jenny-Lips ex Br.-B1. 1950 (figure 3).

Cluster $\mathbf{A}$ is divided into two groups $\mathbf{A 1}$ and $\mathbf{A} 2$ which include especially phytocoenoses from the Papavero-Thymion pulcherrimi alliance belonging to the Cerastio lerchenfeldiani-Papaveretum, Acino-Galietum anisophylli, Saxifragetum moschatae-aizoidis, Doronico columnae-Rumicetum scutati, Cerastio transsilvanici-Galietum lucidi (figure 3).

Group A1 includes phytocoenoses from Piatra Craiului Mountains, which belong to the Cerastio lerchenfeldiani-Papaveretum and Cerastio transsilvanici-Galietum lucidi. Groups with Papaver alpinum subsp. corona sancti-stephani (CLPPC9-Umerii Pietrei Craiului, CLPPC11-Marele Grohotis, CLPPC12-Cerdacul Stanciului) present in the floristic composition a well-defined nucleus of characteristic taxa of the Seslerietalia order that indicate the evolution to phytocoenoses of the rocky meadows (Biscutella laevigata, Achillea oxyloba subsp. schurii, Carex sempervirens, Androsace lactaea, Dianthus spiculifolius, Festuca stricta subsp. saxatilis, Minuartia verna, Ranunculus breyninus, Scabiosa lucida, Seseli libanotis, Sesleria rigida subsp. haynaldiana).

The groups edified by Galium lucidum (CGPC45-Piatra Craiului Mică, CGPC46-Marele Grohotiş) form a separate cluster with Gymnocarpietum robertianae (GRPC59-Marele Grohotiş and GRPC60-Cerdacul Stanciului). Although the communities with Gymnocarpium robertianum belong to the alliance Stipion calamagrostis, in the phytocoenoses of the Piatra Craiului Mountains Gymnocarpium robertianum and Galium lucidum are codominant. The floristic composition is outlined by species that indicate an early lying fallow of the substrate and are also present in Cerastio-Galietum lucidi (Biscutella laevigata, Bupleurum falcatum subsp. cernuum, Carex sempervirens, Festuca stricta subsp. saxatilis, Geranium robertianum, Ranunculus breyninus).

There are two subgroups in group A2 (A2.1 and A2.2):

A2.1 reunites the phytocoenoses of the Acino-Galietum anisophylli from Făgăraș Mountains (AGFG20-Buda, AGFG21-Râiosu), Piatra Craiului Mountains (AGPC16-Grindul Mare, AGPC17Șaua Crăpăturii, AGPC18-Vârful Turnu, AGPC19-Vârful Ascuțit), Bucegi Mountains (AGBC22Colții Morarului) and Godeanu Mountains (AGGO15-Valea Soarbelor) which tend to evolve to rocky meadows from Elyno-Seslerietea class due to the presence of many typical species of these habitats.

Similar groups from Bucegi Mountains (AGBC23-Caraiman, AGBC24-Coștila) and Godeanu Mountains (AGGO14-Curmătura Paltina) form a separate cluster within subgroup A2.2. The latter one have a lower floristic diversity, being less represented the characteristic species of the Seslerietalia order. 
A2.2 includes different syntaxonomically plant coenoses, respectively Cerastio lerchenfeldianiPapaveretum, Doronico columnae-Rumicetum scutati and Acino-Galietum anisophylli.

A large coverage realize both Saxifraga moschata and Saxifraga aizoides in the communities of the Saxifragetum moschatae-aizoidis from Avrigelului Valley (SAFG38-Ciortea, SAFG39-Șeaua Gârbova), along with other species (Cardamine resedifolia, Carex sempervirens, Cortusa matthioli, Chrysosplenium oppositifolium, Cystopteris fragilis subsp. alpina, Lloydia serotina, Pedicularis oederi, P. verticillata, Poa laxa, Potentilla ternata, Primula minima, Soldanella pusilla, Taraxacum panalpinum) that individualize these phytocoenoses from other similar ones of the Făgăraș Mountains.

The phytocoenoses with Rumex scutatus from Buila-Vânturarița Mountains (DRBV28-Muntele Albu, DRBV29-Muntele Ștevioara) are closer, as a floristic composition, to the CerastioPapaveretum (CLPFG2) on the Arpășel Valley.

The groups edified by Rumex scutatus from Tarcu Mountains (DRTA25-Groapa Bistrei) and Făgăraș Mountains (DRFG31-Valea Doamnei, DRFG32-Valea Arpășel) form another cluster. These phytocoenoses are individualized through a nucleus of characteristic species of the Thlaspietalia rotundifolii order (Arabis alpina, Thymus pulcherrimus, Saxifraga aizoides, Galium anisophyllon, Acinos alpinus).

The phytocoenoses of the Saxifragetum moschatae-aizoidis from Făgăraș Mountains (SAFG37Valea Șerbotei, SAFG40-Scara) are more floristically homogeneous due to the coenotic combination of typical species for the Thlaspietalia order (Arabis alpina, Galium anisophyllon, Thymus pulcherrimus, Doronicum carpaticum, Saxifraga oppositifolia, S. paniculata). Saxifraga moschata is found sporadically in the floristic composition, while Dianthus glacialis has a large coverage which determines the existence of the dianthetosum glacialis Voik et Schneider 1978 subassociation.

The groups with Saxifraga aizoides and S. moschata from Țarcu Mountains (SATA33-Sadovanu Peak, SATA34-Groapa Bistrei, SATA35-Obârșia Hidegului), Godeanu Mountains (SAGO36Curmătura Paltina) and Bucegi Mountains (SABC43-Colții Morarului) form a distinct cluster due to the heterogeneous floristic structure comprising species of the Thlaspietalia rotundifolii (Arabis alpina, Cerastium arvense, C. lerchenfeldianum, Galium anisophyllon, Thymus pulcherrimus, Senecio squalidus subsp. rupestris), Seslerietalia (Minuartia verna, Ranunculus breyninus, Acinos alpinus) and Artemisietalia petrosae orders (Artemisia umbelliformis subsp. eriantha, Asplenium viride, Cystoperis fragilis, Saxifraga paniculata).

Cluster B is divided into two groups B1 and B2 that reunite plant communities from the Stipion calamagrostis alliance of the Sedo fabariae-Geranietum macrorrhizi, Achnatheretum calamagrostis, Thymetum comosi, Gymnocarpietum robertianae (figure 3).

Group B1 includes two subgroups (B1.1 and B1.2):

B1.1 includes phytocoenoses of the Thymetum comosi from Buila-Vânturarița Mountains (TCBV95-Cheile Cheii), Leaota Mountains (TCLE87-Curmătura Ghimbavului, TCLE88-Culmea Zacotelor, TCLE91-Cheile Rudăriței, TCLE93-Cheile Mari ale Dâmboviței, TCLE97-Cetățeni), Făgăraș Mountains (TCFG98-Piatra Chiorului, TCFG99-Dealul La Piatră, TCFG100-Cetatea Tălmaciului, TCFG101-Răşinari, TCFG102-Defileul Turnu Roșu), Piatra Craiului Mountains (TCPC94-Cheile Mici ale Dâmboviței).

The communities with Gymnocarpium robertianum from Colțul Surpat (GRLE68) are more structurally similar to the coenoses of the Thymetum comosi teucrietosum montani from Curmătura Ghimbavului (TCLE87) and Culmea Zacotelor (TCLE88) due to the presence of the characteristic 
Current Trends in Natural Sciences

Vol. 10, Issue 19, pp. 209-219, 2021

https://doi.org/10.47068/ctns.2021.v10i19.028

Current Trends in Natural Sciences (on-line)

ISSN: 2284-953X

Current Trends in Natural Sciences (CD-Rom)

ISSN: 2284-9521

ISSN-L: 2284-9521

ISSN-L: 2284-9521

species in which Teucrium montanum and Dianthus spiculifolius, Cyanus triumfettii as differentials species are distinguished.

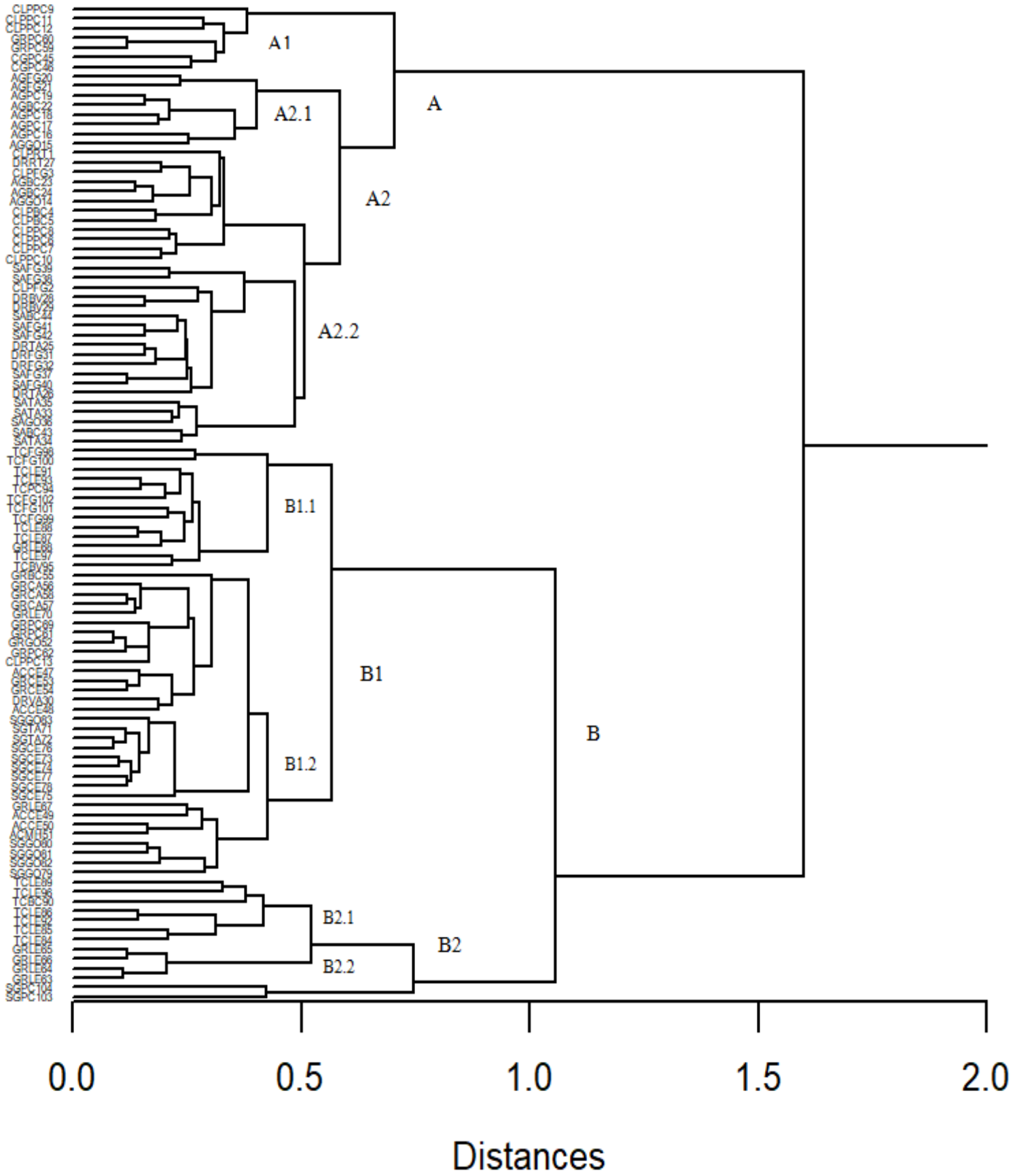

Figure 3. Similarity dendrogram of the surveys of plant associations on calcareous screes from Meridional Carpathians using Relative Euclidian Distance (Ward method) (GR-Gymnocarpietum robertianae; AC-Achnatheretum calamagrostis; TC-Thymetum comosi; SG-Sedo-Geranietum macrorrhizi; CG-Cerastio-

Galietum lucidi; SA-Saxifragetum moschatae-aizoidis; DR-Doronico-Rumicetum scutati; CLP-CerastioPapaveretum; AG-Acino-Galietum anisophylli; RT-Retezat; FG-Făgăraş; TA-Țarcu; GO-Godeanu; CE-Cernei; MH-Mehedinți; VA-Vâlcan; CA-Căpățânii; BV-Buila-Vânturarița; PC-Piatra Craiului; LE-Leaota; BC-Bucegi) 
Phytocoenoses with Thymus comosus from Făgăraș Mountains (TCFG98-Piatra Chiorului, TCFG100-Cetatea Tălmaciului) are more floristically homogeneous, representing successive stages that indicate the evolution to xerophilous meadows due to the presence in the floristic composition of a large number of species from Festuco-Brometea class (Asperula cynanchica, Allium flavum, Stachys recta, Carex humilis, Bothriochloa ischaemum, Teucrium montanum, Dorycnium pentaphyllum subsp. herbaceum, Medicago falcata, Centaurea stoebe subsp. australis, Pimpinella saxifraga, Euphorbia cyparissias, Anthericum ramosum).

Mostly, B1.2 reunite the communities of the Sedo fabariae-Geranietum macrorrhizi, Achnatheretum calamagrostis, Gymnocarpietum robertianae.

The coenoses of the Sedo fabariae-Geranietum macrorrhizi from Godeanu Mountains (SGGO79Cheile Corcoaiei, SGGO80-Ciuceava Ilie Drăgan, SGGO81-Ciuceava Frasin, SGGO82-Ciuceava Mare) differ from those homologous of the Cerna Mountains (SGCE72-78) and Țarcu Mountains (SGTA71-72), through a greater floristic diversity, in which species from Asplenietea trichomanis class (Aurinia petraea, Asplenium ruta-muraria, A. trichomanes, A. viride, Cystopteris fragilis, Dianthus petraeus, Poa nemoralis, Polypodium vulgare, Sedum album, Selaginella helvetica, Veronica bachofenii) are frequently.

The communities with Achnatherum calamagrostis from Prisăcinei Gorges (ACCE50) are floristically similar to those from Prolazului Gorges (ACMH51) having common species as: Arabis procurrens, Aurinia petraea, Ceterach officinarum, Dianthus petraeus, Festuca xanthina, Asperula purpurea, Parietaria officinalis, Sedum album.

The floristic similarities between phytocoenoses with Achnatherum calamagrostis (ACCE47-Cheile Bedinei, ACCE48- Stâncăria Irișor) and those of the Gymnocarpietum robertianae (GRCE53Cheile Prisăcinei, GRCE54-Cheile Bedinei) from Cerna Mountains are explained by the ecological ambiance favourable for heliophilous, xero-thermophilic and eurithermophilic species.

The coenoses of the Doronico columnae-Rumicetum scutati from Sohodolului Gorges (DRVA30) are floristically closer with Achnatheretum calamagrostis from Cernei Valley (ACCE48-Stâncăria Irișor), separating from similar phytocoenoses of the Țarcu Mountains (DRTA25-Groapa Bistrei, DRTA26-Custura Căleanului), Buila-Vânturarița Mountains (DRBV28-Muntele Albu, DRBV29Muntele Ștevioara) and Făgăraș Mountains (DRFG31-Valea Doamnei, DRFG32-Valea Arpășelului). The plant communities with Rumex scutatus from Sohodol Gorges vegetate at lower altitudes in a climate with thermophilic influences like the groups edified by Achnatherum calamagrostis.

The survey from Piatra Craiului Mountains (CLPPC13-Hornul Găinii) belong to the PapaveroThymion pulcherrimi alliance and form a separate cluster with phytocoenoses of the Stipion calamagrostis alliance (Piatra Craiului Mountains: GRPC61-Hornul Găinii, GRPC62-Vlădușca; Godeanu Mountains: GRGO52-Curmătura Paltina), differing from similar groups of the Piatra Craiului Mountains. The explanation would be that the floristic composition is reduced in the CLPPC13 survey, compared with other similar coenoses from Piatra Craiului Mountains, presenting common species with the coenoses of the Gymnocarpietum robertinae from Hornul Găinii (GRPC61) and Vlădușca (GRPC62). Also, Papaver alpinum subsp. corona sancti-stephani is missing in the CLPPC13 survey.

There are two subgroups in group B2 (B2.1 and B2.2):

B2.1 consist of plant communities of the Thymetum comosi and Gymnocarpietum robertianae from Leaota and Bucegi Mountains. 
Phytocoenoses of the Thymetum comosi Pop et Hodişan 1963 galietosum albi (Pop et Hodișan 1964) Coldea 1991 from Bucegi Mountains (TCBC90- stâncile Sfânta Ana) and Leaota Mountains (TCLE84-Colții lui Dumitru, TCLE85-Cheile Crovului, TCLE86-Valea Cheii, TCLE89-Colții Ghimbavului, TCLE92-Cheile Cheii, TCLE96-Colțul Surpat) outlines a cluster in which Galium album has a large coverage and Melica ciliata, Erysimum odoratum appear as differential species.

Cluster B2.2 include phytocoenoses of the Sedo fabariae-Geranietum macrorrhizi from Piatra Craiului Mountains (SGPC103-Valea Seacă and SGPC104-Valea Crăpăturii) that are separated from the homologous groups from Țarcu Mountains (SGTA71-72), Godeanu Mountains (SGGO798) and Cerna Mountains (SGCE73-78). This differentiation is due to the fact that, in the stations from Piatra Craiului Mountains, the groups with Geranium macrorrhizum are closer to beech habitats, so that many species typically for Symphyto-Fagion alliance, Fagetalia order (Luzula luzuloides, Myosotis sylvatica, Sanicula europaea, Scrophularia nodosa, Veronica urticifolia, Cardamine impatiens, Daphne mezereum, Epilobium montanum, Fagus sylvatica, Gentiana asclepiadea, Lonicera xylosteum, Isopyrum thalictroides, Euphorbia carniolica, Heracleum sphondylium, Lapsana communis, Ribes uva-crispa) and Querco-Fagetea class can be found (Acer pseudoplatanus, Athyrium filix-femina, Impatiens noli-tangere, Tanacetum corymbosum, Glechoma hirsuta, Galium schultesii, Geum urbanum, Milium effusum).

\section{CONCLUSIONS}

The hierarchical analysis highlights the floristic similarities between plant associations of the calcareous screes from different massifs of the Meridional Carpathians. Generally, the plant communities were grouped in two main clusters according to their affiliation at the PapaveroThymion pulcherrimi I. Pop 1968 and Stipion calamagrostis Jenny-Lips ex Br.-B1. 1950 alliances.

Due to the specific stational conditions, some communities (CLPPC13, DRVA30, GRPC59, GRPC60) present floristic similarities with groupings belonging to another alliance than the characteristic one.

\section{REFERENCES}

Alexiu, V. (1998). Vegetaţia Masivului Iezer-Păpuşa. Studiu cenotaxonomic [The vegetation of Iezer-Păpuşa Massif. The coenotaxonomic study]. Publishing House Cultura, Piteşti.

Bartók, A., Irimia, I. (2016). Achnatherum calamagrostis (L.) P. Beauv. in the Romanian Carpathians: critical overview, phytocoenotic context and conservation status. Contribuţii Botanice, LI, 27-41.

Beldie, Al. (1952). Vegetaţia Masivului Piatra Craiului [The vegetation of Piatra Craiului Massif]. Buletin Ştiinţific Sect. Şt. Biol. Agron. Geol. şi Geogr., 4(4), 999-1029.

Beldie, Al. (1967). Flora şi vegetaţia Munţilor Bucegi [Flora and vegetation of the Bucegi Mountains]. Publishing House Romanian Academy, Bucureşti.

Boşcaiu, N. (1971). Flora şi vegetaţia Munţilor Ţarcu, Godeanu şi Cernei [Flora and vegetation of the Ţarcu, Godeanu and Cernei Mountains]. Publishing House Romanian Academy, Bucureşti.

Boşcaiu, N., Täuber, F., Coldea, Gh. (1977). Asociaţii vegetale rupicole şi petrofile din Munţii Retezatului [Rupicolous and petrophilous plant associations from Retezat Mountains]. Studii şi comunicări de ocrotirea naturii, Suceava, 253-264.

Chifu, T., Irimia, I., Zamfirescu, O. (2014). Diversitatea fitosociologică a vegetaţiei României. Vegetaţia herbacee naturală (I) [Phytosociological diversity of the Romanian vegetation. Natural herbaceous vegetation (I)]. Publishing House Institutul European, Iaşi.

Ciocârlan, V. (2009). Flora ilustrată a României. Pteridophyta et Spermatophyta [Romanian illustrated flora. Pteridophyta and Spermatophyta] Publishing House Ceres, Bucureşti.

Coldea, Gh., Sanda, V., Popescu, A., Ştefan, N. (2017). Les associations végétales de Roumanie. Les associations herbacées naturelles. Publishing House Presa Universitară Clujeană, Cluj-Napoca. 
Csürös, Şt. (1953). Contribuţii la studiul vegetaţiei alpine din Munţii Făgăraşului [Contribution to the study of alpine vegetation from Făgăraş Mountains]. Buletinul Ştiinţific, Secţ. Şt. Biol., Agron., Geol şi Geogr., V (2), 219-235.

Csürös, Şt., Csürös Kaptalan, M., Pap, S. (1956a). Contribuţiuni la studiul vegetaţiei zonei de calcar din vecinătatea sudică a Munţilor Retezat [Contributions to the study of the limestone vegetation from the vicinity of the southern part of Retezat Mountains]. Studii şi Cerc. de Biol., 1-4, 33-56.

Csürös, Şt., Csürös, Kaptalan M., Nagy, F. (1956b). Contribuţiuni la studiul vegetaţiei alpine a regiunii centrale a Munţilor Retezat [Contributions to the study of the alpine vegetation from the central region of the Retezat Mountains]. Studii şi Cerc. de Biol., 1-4, 56-77.

Diaconescu, F. (1973). Aspecte din vegetaţia Masivului Leaota I [Aspects of the Leaota Massif vegetation I]. Anal. Univ. Al. I. Cuza, Iaşi, secţ. II, Biologie, 19, fasc. 2, 465-474.

Doniţă, N., Ivan, D., Coldea, Gh., Sanda, V., Popescu, A., Chifu, Th., Comănescu-Paucă, M., Mititelu, D., Boşcaiu, N. (1992). Vegetaţia României [Romanian vegetation]. Publishing House Tehnică Agricolă, Bucureşti.

Drăghici, B. (1994). Vegetaţia saxicolă din Valea Dâmbovicioarei şi versantul estic al Pietrii Craiului [The saxicolous vegetation from Dâmbovicioara Valley and eastern part of Piatra Craiului]. Bul. Şt. Fac. Şt. Seria Biologie şi educaţie fizică, Universitatea din Piteşti, 57-88.

Drăgulescu, C. (1995). Flora şi vegetaţia din bazinul Văii Sadului [Flora and vegetation of the basin of Sadului Valley]. Publishing House Constant, Sibiu.

Gafta, D., Mountford, O. (2008). Manual de interpretare a habitatelor NATURA 2000 din România [Interpretation manual of the NATURA 2000 habitats from Romania]. Publishing House Risoprint, Cluj-Napoca.

Maloş, C. (1977). Flora şi vegetaţia cormofitelor din bazinul superior al Motrului [Flora and vegetation of the cormophytes from superior basin of Motru]. Abstract of the PhD Thesis, Universitatea Bucureşti.

Mihăilescu, S. (2001). Flora şi vegetaţia Masivului Piatra Craiului [Flora and vegetation from Piatra Craiului Mountains]. Publishing House Vergiliu, Bucureşti.

Muică, C. (1995). Munţii Vâlcanului. Structura şi evoluţia peisajului [Vâlcan Mountains. Structure and evolution of the landscape]. Publishing House Academia Română, Bucureşti.

Neblea, M. (2007). Flora şi vegetaţia Munţilor Leaota şi al sectorului vestic al Munţilor Bucegi [Flora and vegetation of the Leaota Mountains and the western sector of Bucegi Mountains]. PhD Thesis. Bucureşti: Institutul de Biologie al Academiei Române.

Neblea, M. (2012). Evaluarea gradului de conservare şi cartarea de detaliu a habitatelor (habitate forestiere, de pajişte/fâneţe, grohotişuri) din Parcul Naţional Buila-Vânturariţa [Assessment of the conservation status and detailed mapping of habitats (forestry habitats, grasslands/meadows, screes) in the Buila-Vânturariţa National Park], Project Report POS-Mediu nr. 60/5.05.2011, (unpublished data).

Neblea, M. (2016). Studii de biodiversitate-specii de plante şi habitate naturale din Masivul Leaota [Biodiversity studyplant species and natural habitats from Leaota Massif]. Project Report financed by Conservation Carpathia Foundation, (unpublished data).

Neblea, M., Marian, M. (2020). Phytosociological considerations regarding siliceous screes from Meridional Carpathians (Romania), Oltenia. Studii și Comunicări Științele Naturii, 36 (1), 195-202.

Nicolae-Biţă, D. C. (2005). Flora şi vegetaţia bazinului superior a râului Prahova [Flora and vegetation of the superior basin of Prahova river]. PhD Thesis. Bucureşti: Institutul de Biologie al Academiei Române.

Păun, M., Popescu, Gh. (1978). Date despre vegetaţia ierboasă a catenei calcaroase Buila-Vânturariţa din Munţii Căpăţânii, jud. Vâlcea [Data regarding herbaceous vegetation of the Buila-Vânturariţa calcareous part from Căpăţânii Mountains, Vâlcea County]. Analele Univ. Craiova, IX(XIX), 67-73.

Păun, M., Popescu, Gh. (1978). Aspecte din vegetaţia Văii Sohodolului. Jud. Gorj [Aspects from Sohodolului Valley vegetation]. Studii şi Cercetări, Târgu Jiu, 93-96.

Pop, O. G. (2009). Cercetări asupra diversităţii fitotaxonomice din Parcul Naţional Piatra Craiului cu accent pe monitorizarea grohotişurilor calcaroase [Researches concerning phytotaxonomical diversity from Piatra Craiului National Park with emphasis on monitoring of the calcareous screes]. PhD Thesis. Bucureşti: Universitatea Bucureşti.

Popescu, Gh. (1974). Studiul floristic şi geobotanic al bazinului hidrografic al Bistriţei-Vâlcii [Floristic and geobotanical study of the hydrographic basin of Bistriţei-Vâlcii]. PhD Thesis. Bucureşti: Universitatea Bucureşti.

Puşcaru-Soroceanu, E., Csürös, Şt., Puşcaru, D., Popova-Cucu, A. (1981). Die vegetation der Wiesen und Weiden des Făgăraş-Gerbiges in den Südkarpaten, Phytocoenologia, 9(3), 257-309.

Răduţoiu, D. (2008). Flora şi vegetaţia bazinului Cernei de Olteţ [Flora and vegetation of the Cerna-Olteţ basin]. Publishing House Sitech, Craiova. 


\section{Current Trends in Natural Sciences}

Vol. 10, Issue 19, pp. 209-219, 2021

https://doi.org/10.47068/ctns.2021.v10i19.028

Current Trends in Natural Sciences (on-line)

Sanda, V., Popescu, A. (1976). Contribuţii la cunoaşterea vegetaţiei de stâncării din Masivul Piatra Craiului [Contributions to the knowledge of the rocky vegetation from Piatra Craiului Massif]. Contribuţii Botanice, 149160.

Sanda, V., Popescu, A., Doltu, M. I. (1977). Vegetaţia Masivului Piatra Craiului [The vegetation from Piatra Craiului Massif]. Studii şi Comunicări-Ştiinţe Naturale, Muzeul Bruckenthal, Sibiu, 21, 115-212.

Sanda, V., Popescu, A. (1991). Aspecte ale vegetaţiei din culoarul Cernei [Vegetation aspects from Cerna corridor]. Ocrotirea Naturii şi a Mediului Înconjurător, 35 (1-2), 27-34.

Sanda, V., Popescu, A., Fişteag, G. (1996). Aspecte de vegetaţie din Parcul Naţional Bucegi [Vegetation aspects from Bucegi National Park]. Naturalia. Studii şi Cercetări, II-III, 193-204.

Sârbu, I., Ştefan, N., Oprea, A. (2013). Vascular plants of Romania. An illustrated field guide. Publishing House Victor B Victor, Bucharest.

Schneider-Binder, E. (1970). Aspecte din flora şi vegetaţia conglomeratelor Tălmaci-Podul Olt (jud. Sibiu) [Aspects of flora and vegetation of the Tălmaci-Podul Olt conglomerates (Sibiu County)]. Studii şi Comunicări-Ştiinţe Naturale, Muzeul Bruckenthal, Sibiu, 15, 161-186.

Stancu, I. D. (2005). Flora şi vegetaţia Munţilor Râiosu şi Buda, Masivul Făgăraş [Flora and vegetation of Râiosu-Buda Mountains, Făgăraş Massif]. Publishing House Universitatea din Piteşti.

Voik, W. (1976). Vegetaţia alpină din Valea Şerbotei (Munţii Făgăraşului) [The Alpine vegetation from Şerbota Valley (Făgăraş Mountains)]. Studii şi comunicări-Ştiinţe Naturale, Muzeul Bruckenthal, Sibiu, 20, 47-64.

Voik, W., Schneider-Binder, E. (1978). Cercetări asupra asociaţiilor de grohotişuri (Thlaspietea rotundifolii Br.-Bl. 1926) din etajul alpin al Munţilor Făgăraş [Researches concerning screes associations (Thlaspietea rotundifolii Br.-B1. 1926) from alpine level of Făgăraş Mountains]. Studii şi comunicări-Ştiinţe Naturale, Muzeul Bruckenthal, Sibiu, 22, 189-202.

****, 1952-1969. Flora R.P.R.-R.S.R., Publishing House Romanian Academy, Bucharest.

http://ww2.bgbm.org/EuroPlusMed/query.asp.

http://www.bucegipark.ro/ 